\title{
PEDAGOGIA PRYMASA TYSIĄCLECIA KARDYNAŁA STEFANA WYSZYŃSKIEGO
}

\section{Pedagogy of the Primate of the Millennium, Cardinal Stefan Wyszyński}

S u m m a r y: An analysis of source texts and selected biographical studies of Cardinal Stefan Wyszyński was carried out from the perspectives of the processes of secularization taking place in Poland in the year AD 2020, the radical attacks of left-wing politicians on the Catholic Church and its relationship with the current governing coalition known as the United Right [Zjednoczona Prawica]. This strikes at the foundations of the Second Vatican Council and the role of the Polish Church in regaining the nation's freedom from socialist domination in 1989. The author therefore recalls not only the exceptional merits of the Polish Primate during the period of totalitarianism of the „People's Poland” [Polska Ludowa], but also his message to educator-practitioners, parents, and scientists.

Ke y w o r d s: Catholic Church, totalitarianism, upbringing, resistance, prowess, ethics, axiology, pedagogy

${ }^{1}$ Bogusław Śliwerski - prof. zw. dr hab., dr h.c., pedagog, kierownik Katedry Teorii Wychowania Uniwersytetu Łódzkiego, prof. zw. Akademii Pedagogiki Specjalnej im. M. Grzegorzewskiej w Warszawie; Przewodniczący Sekcji Nauk Humanistycznych i Społecznych Centralnej Komisji ds. Stopni i Tytułów; członek wielu towarzystw naukowych polskich i zagranicznych. Autor znakomitych książek naukowych i podręczników akademickich, m.in.: Wspótczesne teorie i nurty wychowania (1998, IX, ed. 2015); Wspótczesna myśl pedagogiczna. Znaczenia. Klasyfikacje. Badania (2009); Pedagogika ogólna. Podstawowe prawidłowości (2012); Diagnoza uspołecznienia publicznego szkolnictwa III RP w gorsecie centralizmu (2013); Edukacja (w) polityce. Polityka (w) edukacji (2015); Meblowanie szkolnej demokracji (2017); Książki (nie)godne czytania? (2017); Habilitacja. Diagnoza. Procedury. Etyka. Postulaty (2017); Turystyka habilitacyjna Polaków na Słowacje w latach 2005-2016 (2018); Pedagogia harcerskiego wychowania (2018). Adres do korespondencji: ul. Pomorska 46/48, 91-408 Łódź; adres e-mail: boguslawsliwerski@gmail.com. 
Wielkość postaci historycznej mierzy się także zainteresowaniem jej życiem przez kolejne pokolenia ${ }^{2}$.

Społeczne nauczanie Kardynała Stefana Wyszyńskiego wzbudza zainteresowanie swoją aktualnością nie tylko w kręgach duszpasterskich, co jest zupełnie naturalne, ale także we wspólnotach akademickich, gdzie kształci się przyszłe pokolenia wychowawców, pedagogów, rodziców i osoby służby publicznej. Lata 2017-2020 przyniosły w życiu społeczno-politycznym naszego kraju z jednej strony kontrrewolucyjną zmianę polityczną, aksjonormatywną ${ }^{3}, \mathrm{z}$ drugiej zaś poważny kryzys polityczny na tle światopoglądowych różnic i podziałów ${ }^{4}$ oraz radykalny spadek religijności wśród młodzieży ${ }^{5}$. Wydaje się zatem konieczne przypomnienie kluczowych dla przemian w polskim Kościele i życiu społecznym Polaków poglądów Prymasa Tysiąclecia. Są one bowiem kluczowe ze względu na ich głębokie zakorzenienie w osobistych losach i doświadczeniach okresu okupacji oraz w dramatycznym pozbawieniu Go przez reżim minionego ustroju prawa do przewodzenia Kościołowi katolickiemu w naszej ojczyźnie. Sięgam zatem po kategorię oporu, normatywna wizja wychowania została już bowiem opracowana w wielu publikacjach naukowych. Nie ma zatem potrzeby, by ją w tym miejscu odtwarzać.

Kształtowanie ludzkiej świadomości w kulturze jest nie tylko procesem przystosowania się do istniejących sposobów myślenia i interpretowania bieżących wydarzeń, uprawomocniających dany stan rzeczy, ale także terenem walki podporządkowanych i poddanych opresji grup z siłami dominacji wobec innych. Wychowanie i kształcenie są zarówno miejscem przemocy, jak i oporu, terytorium, na którym krzyżują się niezliczone i różnorodne działania zewnętrzne wielu podmiotów, instytucji, środowisk, ale i prób dominacji nad człowiekiem z pozbawieniem go praw i prawd. Osoby potęgujące wewnętrzne oraz zewnętrzne skłócenie i niepokój prowadzą nie tylko do kryzysu religijnego w państwie, jak pisał Wyszyński w 1967 roku, do przybierającej formę "psychozy opadających dłoni” walki społecznej, do „[...] wyczerpującej i wyniszczającej współczesną młodzież niekończącej się wojny wszystkich z wszystkimi”'. Od kilku lat Polacy odczuwają skutki wojny kulturowej, aksjonormatywnej, wszystkich ze wszystkimi, jaka toczy się w świecie równoległym (wirtualnym) i realnym. To w Internecie zaczyna odgrywać istotną rolę symulanctwo moralne w postaci postprawd i fake newsów,

2 Andrzej Grajewski, „Prowadził ich przez mrok”. W: Ewa K. Czaczkowska, Kardynał Wyszyński. Biografia (Kraków: Wydawnictwo Znak, 2013), 5.

${ }_{3}^{3}$ Bogusław Śliwerski, [Kontr] rewolucja oświatowa. Studium z polityki prawicowych reform edukacyjnych (Łódź: Wydawnictwo Uniwersytetu Łódzkiego, 2020).

${ }^{4}$ Michał P. Markowski, Wojny nowoczesnych plemion. Spór o rzeczywistość w epoce populizmu (Kraków: Wydawnictwo Karakter, 2019).

${ }^{5}$ Janusz Mariański, Kondycja religijna i moralna młodzieży szkół średnich w latach 1988-1998-20052017 (raport z ogólnopolskich badan socjologicznych) (Toruń: Wydawnictwo Adam Marszałek, 2018).

${ }^{6}$ Alina Rynio, Wychowanie młodzieży w nauczaniu Kardynała Stefana Wyszyńskiego (Lublin: Redakcja Wydawnictw KUL), 43. 
które są wytwarzane przez obie strony ideowych sporów w myśl zasady, że „[...] aby żyć trzeba kłamać"7.

Dzielność, odwaga stawały się najważniejszymi z cnót obywatelskich w czasach komunistycznej zarazy. Zdaniem historyków Polacy żyli w wielostronnej niewoli, toteż ich aktywny udział w uroczystościach religijnych stawał się nie tylko manifestacją wiary, ale także „[...] szkołą obywatelskiego myślenia i działania. Ludzie uczyli się, że sami, nie z nakazu, mogą coś zrobić: przygotować trasę przejazdu obrazu, przystroić ulice. To był bardzo ważny moment w umacnianiu niezależności społeczeństwa". W najtrudniejszych dla naszego narodu czasach totalitaryzmu nazistowskiego i bolszewickiego ${ }^{9}$ ksiądz kardynał Stefan Wyszyński podtrzymywał w Polakach poczucie wolności i niezależności krytykując tych, którzy dawali przykład ucieczki od wolności:

[...] większości katolickich inteligentów brakuje kręgosłupa moralnego. Gotowi są iść na układy z komunistyczną władzą, dając się nawet użyć przeciw Kościołowi [...] wielu ludzi załatwia biurokratyczne obstalunki ideowe komunizmu [...] tworzy się warstwa ludzi tchórzliwych, którzy pospolite tchórzostwo, zamykające im usta przed wyznaniem prawdy, nazywają roztropnością. Jest to szkodliwe ${ }^{10}$.

\section{Wychowanie i nauczanie społeczne}

Ćwierć wieku temu Alina Rynio wydała podoktorską rozprawę o wychowaniu młodzieży w nauczaniu Prymasa Tysiąclecia ${ }^{11}$. Były to pierwsze lata transformacji ustrojowej, okres wielkiej nadziei na zmianę m.in. paradygmatu kształcenia i wychowania młodych pokoleń. Konieczne było przywołanie nieobecnej przez lata quasi-totalitarnego ustroju pedagogii myśli humanistycznej, która była przedmiotem cenzury i naukowego wykluczania. Zrozumiały wydawał się też zachwyt zachodnią literaturą pedagogiczną, gdyż polska pedagogika potrzebowała - mimo wieloletniej nieobecności w światowym dyskursie edukacyjnym - szybkiego włączenia się do aktualnych debat oraz badań nad wychowaniem i kształceniem młodych pokoleńn ${ }^{12}$. Zaczynaliśmy budować nowe społeczeństwo, toteż przybliżenie po raz pierwszy

7 Tamże, 47.

${ }^{8}$ Za: Czaczkowska, Kardynał, 301.

9 Zob. Teresa Hejnicka-Bezwińska, „Pedagogika socjalistyczna”. W: Pedagogika, red. Zbigniew Kwieciński, Bogusław Śliwerski (Warszawa: WN PWN, 2019), 189-202; Janina Kostkiewicz, Polski nurt krytyki nazizmu przed rokiem 1939. Aspekty ideologiczne i pedagogiczne (Kraków: Wydawnictwo ARCANA, 2020); Stalinizm, red. Jacek Kurczewski (Warszawa: Uniwersytet Warszawski. Instytut Profilaktyki Społecznej i Resocjalizacji, 1989).

${ }_{10}$ Czaczkowska, Kardynał, 383.

${ }^{11}$ Rynio, Wychowanie.

12 Zob. Ku pedagogii pogranicza, red. Zbigniew Kwieciński, Lech Witkowski (Toruń: Wydawnictwo UMK, 1990); Bogusław Śliwerski, Współczesne teorie i nurty wychowania (Kraków: Impuls, 1998). 
w tak syntetycznym ujęciu podejścia Kardynała Stefana Wyszyńskiego do wychowania, rozumianego jako „[...] praca nad człowiekiem przy współudziale jego samego jako osoby będącej na etapie dojrzewania i rozwoju"13, wnosiło wyjątkowy dar budzenia nadziei. W środowisku pedagogicznym ważne było osiąganie przez każdy podmiot oddziaływań wychowawczych „[...] pełni życia świadomego swej tożsamości i powołania w kontekście, w którym człowiekowi przyszło żyć i realizować swą osobowość"14.

Trafny jest pogląd Aliny Rynio, by nie przypisywać opublikowanym wypowiedziom Wyszyńskiego języka nauk pedagogicznych. Doskonale jednak zdajemy sobie sprawę z tego, że właśnie pedagogika jako nauka o wychowaniu czerpie swoje bogactwo i rozwija się - zresztą nie tylko w naszym kraju - bez porzucania prymarnych dla niej źródeł tkwiących w filozofii, historii myśli i doktryn społecznych, jak i szeroko pojmowanej humanistyce, $\mathrm{w}$ tym - w tak ważnych dla nurtu pedagogiki chrześcijańskiej - nauk teologicznych. Przecież jednym z wiodących myślicieli i wzorów osobowych przełomu ustrojowego dla kolejnych pokoleń Polaków był - obok Jana Pawła II oraz filozofa solidarnościowej formacji ks. prof. Józefa Tischnera - właśnie Prymas Polski kardynał Stefan Wyszyński. Niesłusznie współcześni pedagodzy wciąż jeszcze nie dostrzegają w rozwoju nauk humanistycznych i społecznych konieczności uwzględniania wzajemnego przenikania wiedzy i odkryć oraz ich interpretacji zarówno w obrębie jednego paradygmatu, jednej metodologii badań, jak i pomiędzy nimi, w poprzek, skoro społeczeństwo, dla potrzeb którego badamy procesy wychowania i kształcenia, nie jest ani jednorodne, ani jednolite, ani monokulturowe czy tym bardziej pozbawione różnic światopoglądowych.

We współczesnej pedagogice życie, dokonania, myśl i nauczanie Prymasa wpisują się w wyjątkową, a wciąż badaną przez współczesnych humanistów tradycję rozwoju nauki społecznej Kościoła katolickiego oraz w jej zakresie - także pedagogiki chrześcijańskiej, która miała swoich mistrzów w okresie II Rzeczypospolitej ${ }^{15}$. On sam nawiązuje w swoim homo- i chrystocentrycznym personalizmie katolickim do filozofii św. Tomasza $\mathrm{z}$ Akwinu, integralnego humanizmu J. Maritaina, wydobywając jej znaczenie dla nauki o godności ludzkiej osoby, która może rozwijać swój potencjał, doświadczając wzajemnie dopełniających się porządków świata: naturalnego i nadprzyrodzonego. Jak powiadał: „[...] nie można się lękać wielkości człowieka, ale wychowywać go do niej, by wykorzystał ją »dla dobra osobistego, narodowo-społecznego i państwowego «"16. Zdaniem

13 Tamże, 12.

14 Tamże, 13.

15 Zob. Stanisław Dziekoński, Rozwój wychowawczej myśli Kościoła na przestrzeni ostatnich wieków (Warszawa: Wydawnictwo Uniwersytetu Kardynała Stefana Wyszyńskiego w Warszawie, 2004); tenże, Formacja chrześcijańska dziecka $w$ rodzinie $w$ nauczaniu Kościoła od Leona XIII do Jana Pawła II (Warszawa: Wydawnictwo Uniwersytetu Kardynała Stefana Wyszyńskiego, 2006).

${ }^{16}$ Czaczkowska, Kardynał, 661. 
Kardynała Wyszyńskiego człowiek jako osoba społeczna rozwija swoją osobowość, umiejętności, kształtuje postawy i sumienie we wspólnocie, jaką jest najpierw rodzina, a później pojawiająca się instytucjonalnie pedagogika przedszkolna, szkolna i środowiskowa. Funkcję familia humana wzbogacają swoimi oddziaływaniami inne wspólnoty, jak np. parafialna czy środowiska socjalizacyjne, np. stowarzyszenia (harcerskie, studenckie, sportowe, kulturalne itp.), a nawet wspólnoty międzynarodowe (rodzina rodzin).

Wizję państwa, Kościoła, oświaty szkolnej, nauki i kultury Wyszyński osadzał w nurcie antropologiczno-filozoficznym doktryny społecznej Kościoła katolickiego. $\mathrm{Na}$ jej podstawie konstruował wizerunek człowieka, obywatela jako świadomej, wolnej i potencjalnie kreatywnej istoty posiadającej godność, ale i społeczeństwa wraz ze zróżnicowanymi w nim grupami społecznymi. Pasterz Kościoła katolickiego w Polsce konsekwentnie przypisywał pierwszeństwo osobie ludzkiej, której prawa muszą być uszanowane w państwie. Odnoszę się w tym miejscu tylko do pierwszego porządku, a więc przyrodzonego, jako jednego $\mathrm{z}$ fundamentów niepowtarzalności bytu ludzkiego. Teolodzy uwzględniają jeszcze w swoich studiach porządek transcendentny godności ludzkiej. Można zauważyć w rozprawach S. Wyszyńskiego, jak ważną rolę miały odgrywać w państwie cztery filary kultury, a mianowicie: nauka, religia, wychowanie i szkoła, które postrzegał jako dobro wspólne wszystkich obywateli.

Szkoła jest narodowa i należy do narodu, do rodziny i społeczeństwa, a nie do takiej czy innej partii, sekty czy ugrupowania zajmującego się niechwalebnym, a nawet wrogim i szkodliwym dla Narodu i państwa dziełem - wyrywania Boga z serc dzieci i młodzieży. [...] nie ma takiej władzy na ziemi, która mogłaby bez pogwałcenia wolności odmówić rodzicom prawa do wychowywania dzieci w duchu religijnym ${ }^{17}$.

To na władzy państwowej powinien spoczywać obowiązek zatroszczenia się o związane z tym wartości, jak prawda, wolność, sprawiedliwość i miłość.

Kategorię wolności ujmował Prymas Tysiąclecia dwoiście, jako wzajemnie dopełniające się wolności. Jedną jest wolność wewnętrzna osoby, jaką stanowi jej praca nad sobą. „Praca wewnętrzna jest najsubtelniejszym trudem, wymaga stałej czujności, by poprawić w sobie miłość"18. Drugą zaś jest wolność zewnętrzna, która polega na przezwyciężaniu przemocy ze strony władzy. Jak pisał w jednym $\mathrm{z}$ rozdziałów dysertacji doktorskiej zatytułowanym Prawa rodziny, Kościoła i państwa do szkoły - w sferze wychowania religijnego najważniejsze podmioty tego procesu powinny ze sobą współdziałać bez naruszenia naturalnego, prymarnego prawa rodziców do kierunku owego procesu. Nie mógł zatem pogodzić się z usunięciem po wojnie ze szkół państwowych lekcji religii. „Cóż

17 Tamże, 665.

18 Stefan Wyszyński, Pro Memoria, t. 1: 1948-1952 (Warszawa: Archidiecezja Warszawska i Archidiecezja Gnieźnieńska, IPN-Komisja Ścigania Zbrodni przeciwko Narodowi Polskiemu, UKSW, 2017), 218. 
bardziej wrogiego społeczeństwu, jak żądać od milionów, by przestały chodzić do Kościoła dlatego, że urzędnik minister nie modli się? Cóż bardziej dzikiego, jak wypędzać religię ze szkół, przedszkoli, dlatego, że władcy nie uczyli się religii lub stracili wiarę?”19.

Wychowanie w głęboko religijnej i patriotycznej atmosferze oraz utrata matki jako najważniejszej osoby w życiu sprawiły, że S. Wyszyński przeniósł miłość na Matkę Bożą. Wierzył też w duchową obecność zmarłej matki: „Nieraz mi się wydaje, gdy stoję na ambonie, że za mną stoi moja przedwcześnie zmarła Matka. Gdy podejmuję i prowadzę jakieś wyjątkowo ciężkie prace, to mam wrażenie, że Ona mi doradza i podpowiada" ${ }^{20}$. Nie tylko z racji uwielbienia dla Matki Bożej Częstochowskiej Wyszyński został nazwany Prymasem Jasnogórskim, ale także dlatego, że przebywał na Jasnej Górze łącznie 603 dni, podejmując tam najważniejsze decyzje ${ }^{21}$.

Odczytuję w biografii S. Wyszyńskiego wyjątkowe świadectwo introjekcji wartości harcerskich. Jako gimnazjalista potwierdził przed swoją drużyną w akcie przyrzeczenia harcerskiego szczerą wolę pełnienia służby Bogu i ojczyźnie. Danego słowa dotrzymał, o czym świadczy fakt, że za udział w manewrach drużyny ze współdziałającą z nią Polską Organizacją Wojskową został wraz z kolegami ukarany przez Niemców chłostą. Wstąpienie w 1917 roku do Niższego Seminarium Duchownego we Włocławku zapoczątkowało kapłańską drogę do najwyższej godności w kraju, jaką było objęcie stanowiska Prymasa Polski. Znakomicie wykształcony na Katolickim Uniwersytecie Lubelskim w zakresie teologii i po uzyskaniu stopnia naukowego doktora prawa kanonicznego prowadził badania do swojej rozprawy habilitacyjnej, której nie było mu dane ukończyć ze względu na wybuch II wojny światowej, a także na skutek utraty zgromadzonych materiałów badawczych. Nie podjął jednak po okupacji ścieżki pracy akademickiej, angażując się w pracę duszpasterską, charytatywną i dobroczynną.

Jeszcze w okresie II Rzeczypospolitej S. Wyszyński wyrażał stanowczy opór przeciwko fali przenikającej do kraju ideologii komunistycznej, która niosła z sobą idee ateizmu i wrogości wobec wszelkiej religijności, duchowości w życiu człowieka. Postrzegał zatem Polskę jako przedmurze chrześcijaństwa.

Ostatecznym celem komunizmu nie jest poprawa stosunków społeczno-gospodarczych, nie jest sprawiedliwość społeczna, ani też dążenie do poprawy bytu ludności. Bolszewizm sprawiedliwość społeczną mechanizuje, doprowadzając do likwidacji praw jednostki na korzyść społeczeństwa. Celem bolszewizmu jest ogólnoświatowy przewrót cywilizacyjny, wyniszczenie kultury chrześcijańskiej, do którego to celu chce skierować siły inteligencji ${ }^{22}$.

19 Za: Czaczkowska, Kardynał, 75.

${ }^{20}$ Tamże, 33.

${ }^{21}$ Anna Rastawicka, Ten zwycięża, kto miłuje, Mt 5,14 (Warszawa: Muzeum Jana Pawła II i Prymasa Wyszyńskiego, 2020).

${ }_{22} \mathrm{Za}$ : Czaczkowska, Kardynał, 56. 
Podobny pogląd wyrażali wybitni pedagodzy tego pokolenia - Sergiusz Hessen (1930) i Aleksander Kamiński (1942). Jan Paweł II określił swój stosunek do totalitarnych reżimów i ich ideologii w ostatnim dziele zatytułowanym Pamięć i tożsamość. Wskazał w nim na dwa potężne systemy totalitarne - nazizm w Niemczech i komunistyczny „realny socjalizm” Związku Radzieckiego - jako odpowiedzialne za niezliczone zbrodnie w dziejach ludzkości. Słusznie pytał: „Czy można w tych wydarzeniach nie dostrzegać czynnej obecności misterium iniquitatis? Jednakże obok zła nie brakowało dobra. Dyktatury, które zapanowały poza »żelazną kurtyną «, nie zdołały zdusić pragnienia wolności w poddanych im narodach"23. Z tymi zbrodniami i ich pozostałościami musiał zmagać się Prymas Tysiąclecia od początku okresu stalinizmu do końca PRL-owskiego reżimu i początków polskiej transformacji, doświadczając wiele przemocy, cierpień i upokorzeń, szczególnie w trwającym trzy lata okresie internowania (25 września 1953-26 października 1956).

Dopiero sięgając do biografii S. Wyszyńskiego z okresu brutalnego stalinizmu, możemy zrozumieć powody poruszania przez Kardynała w kazaniach, publikacjach i spotkaniach $\mathrm{z}$ wiernymi problemu rozkładu moralnego w polskim społeczeństwie, niszczenia jego elit, odchodzenia od teologii moralnej w wyniku bezdusznego poniżania człowieka i deprecjonowania roli państwa narodowego w Europie ojczyzn. Dramatyczne były warunki, w jakich przyszło Prymasowi pełnić służbę. Przyjęta dnia 22 lipca 1952 roku przez Sejm Konstytucja Polskiej Rzeczypospolitej Ludowej usankcjonowała państwo totalitarne w jego zależności od Związku Sowieckiego.

To nie PZPR organizuje walkę z Kościołem; partia tylko ją prowadzi. Ale organizacja należy do Moskwy. Wolę wiedzieć, że to czyni Moskwa. Z prześladowaniem Kościoła przez Moskwę jesteśmy oswojeni, ale z prześladowaniem Kościoła przez rząd polski, zwłaszcza ludowy, trudno się pogodzić ${ }^{24}$

- głosił prymas.

Zaczął się okres odbierania i całkowitego niszczenia przez władze komunistyczne wszystkiego, co było reprezentatywne dla katolickiego społeczeństwa, którego ostoją była prasa katolicka, wydawnictwa katolickie, żłobki i przedszkola, szkoły, a także szpitale i zakłady opieki. Księża byli poddawani pełnej inwigilacji służb bezpieczeństwa, zaś tzw. „księżom-patriotom” władze oddawały kierownicze stanowiska w strukturach kościelnych. Rewizje duchowieństwa, presje stosowane wobec niego, gwałcenie praw człowieka, aresztowania księży pod byle pozorem czy kiedy uświadamiali rodzicom ich prawo i obowiązek upominania się o religię w szkole, były przejawem stosowanej przez władze represji nie tylko wobec duchownych, które miały na celu ich upodlenie pod osłoną działania państwowego.

${ }^{23}$ Jan Paweł II, Pamięć i tożsamość. Rozmowy na przełomie tysiącleci (Kraków: Wydawnictwo Znak, 2005), 5.

${ }^{24}$ Wyszyński, Pro Memoria, t. 1: 1948-1952, 137. 
Było to działanie przygotowujące grunt do ateizacji dzieci i młodzieży oraz zniszczenia wolności politycznej i pluralizmu w polskim społeczeństwie. Usunięto ze szkół nauczanie religii, które pozostało zdane wyłącznie na środki i warunki parafii. Rozpoczął się okres przejmowania przez komunistyczny aparat władzy kościelnej organizacji charytatywnej Caritas, znacjonalizowania majątków ziemskich związków wyznaniowych i Kościoła katolickiego oraz intensywny atak na Stolicę Apostolską i papieża Piusa XII, a także polskich biskupów i kardynałów. Współczesne pokolenie nie zdaje sobie sprawy z tego, jak wielkie obciążenia i jak ogromna odpowiedzialność spadła na prymasa, gdy

[...] w obliczu braku suwerenności narodu poddanego komunistycznej opresji brał na swoje barki trud jego wychowania, a także - w miarę swych możliwości - obrony przed niebezpieczeństwami płynącymi zarówno od wewnątrz, jak i z zewnątrz, w pewnym sensie reprezentując naród wobec władz komunistycznych, jak i wobec czynników zewnętrznych ${ }^{25}$.

Szczególnie Dzienniki kardynała S. Wyszyńskiego znakomicie oddają jego misję na rzecz nie tylko ocalenia polskiego Kościoła, wiary i religii w okresie PRL, ale także morale polskiego narodu. Pisał w nich o potrzebie tworzenia przestrzeni dla reprodukcji wysokiej kultury, rozwoju intelektualnego, aktywności społecznej i artystycznej obywateli i młodych pokoleń. We wstępie do pierwszego tomu Dzienników potwierdził to biskup Jan Kopiec: „Kościół katolicki w naszym kraju był w okresie PRL wyjątkową - w skali całego bloku państw komunistycznych silną instytucją społeczną, nad którą rządzącym komunistom nigdy nie udało się przejąć kontroli”26.

\section{Kościół a polityka}

Mimo iż kardynał Wyszyński odmawiał księżom politycznego angażowania się, to jednak jako Prymas musiał być politykiem, dyplomatą, a w czasie zagranicznych podróży także ambasadorem kraju i jego mieszkańców. „Uważał, że katolicy mają obowiązek uczestniczyć w polityce [...], ale musi być to obecność »katolicka«. Nie można bronić skutecznie praw Narodu przeciw prawom Boga, bo wtedy podcina się gałąź, na której się siedzi"27. Posiadał przy tym wyjątkowy talent koncyliacyjny, dar do mediowania z każdą władzą, gdy pojawiały się konflikty, przy czym w sytuacji ewidentnej opresji wobec niego przyjmował postawę milczącego znoszenia cierpienia, by nie zaostrzać spraw ważnych dla społeczeństwa i Kościoła. W tej sferze bywał bardzo osamotniony w relacjach $\mathrm{z}$ władzami państwowymi.

\footnotetext{
25 Tamże, XI-XII.

26 Tamże, XI.

27 Czaczkowska, Kardynał, 158.
} 
Prymasowi, który był wychowany w głębokim patriotyzmie, umiłowaniu ojczyzny i szacunku dla władzy, trudno było chyba przyjąć, że głowa państwa może działać na szkodę własnego narodu. Że polityka represji, prześladowań, niszczenia wszelkich przejawów niezależności społeczeństwa może być celem jego działań ${ }^{28}$.

Prymas roztropnie analizował każde posunięcie, taktykę władzy, którą określał mianem „[...] »robaka « usiłującego stoczyć Kościół od wewnątrz”29. Analizował każdy, nawet najmniejszy gest władzy pod kątem dobrej woli, który w istocie okazywał się jedynie pozorowaniem współpracy rządu z episkopatem. Umacniał biskupów w konieczności trwania w służbie Bogu i ojczyźnie, nieulegania władzy nawet, gdyby miało to się wiązać $\mathrm{z}$,utratą wolności” czy stanowisk. Prymas nie był zwolennikiem rewolucji społecznych. Uważał, że zmiany w państwie, bez względu na to, jakie są ich źródła i powody, powinny następować ewolucyjnie, z przyzwoleniem obywateli, a nie pominięciem ich woli, kultury i potrzeb.

Bywało, że nakłaniał rodziców do oporu wobec antyreligijnej polityki władz państwowych. Jednak przede wszystkim nawoływał księży do włączenia się w walkę rodaków o prawa Kościoła w kraju, by stawali wiernie przy Kościele: „Wiem, że czeka nas ciężka walka, walka, gdzie niejeden kapłan odda swe życie za wiarę, lecz przy poparciu narodu, który wiernie będzie stał przy wierze na każdym kroku zwyciężymy" ${ }^{30}$. Wzywał także do nieposłuszeństwa obywatelskiego, kiedy w okresie stalinizmu i PRL z jednej strony zakazywał księżom angażowania się w politykę władz państwowych, a $z$ drugiej strony wyzwał wiernych do nieposyłania dzieci do szkół, z których usunięto religię. „Uznajemy tylko takie wychowanie, które - przy całej zdrowej trosce o ciało i wyrobienie społeczne - nie zapomina o Stworzycielu ciała i duszy ludzkiej, o Bogu"31.

Prymas był przekonany, że Polska potrzebuje rozumnego rządu, który nie będzie kierował się w wewnętrznej polityce ciasnym ateizmem, walką religijną i antydemokratycznym postępowaniem, ale będzie potrafił pogodzić polski model marksizmu, upaństwowionego materializmu z narodem o światopoglądzie katolickim. „On po prostu wychował się w przekonaniu, że między Kościołem a państwem musi istnieć sfera choćby minimalnego współdziałania. Każde z nich ma inne zadania do spełnienia, ale zwracają się do tego samego obywatela i nie można dopuścić do konfliktu między nimi”32. Pozbawianie Kościoła jego praw do prowadzenia nauki społecznej, wychowywania młodych pokoleń i służenia wiernym, także do jego ziem i majątków, siłą, terrorem, manipulacją i cenzurą naruszanie prawa Kościoła do samostanowienia o własnej hierarchii, złamanie zasad obsadzania stanowisk kościelnych i umieszczania na nich zdrajców w osobach

\footnotetext{
28 Tamże, 167.

29 Tamże, 174.

30 Tamże, 103.

31 Tamże, 78.

32 Tamże, 108.
} 
księży „patriotów”, a nawet posunięcie się do uwięzienia Prymasa, by zastąpić go uległą władzy hierarchią, miało na celu całkowite zniszczenie polskiego Kościoła. Kardynał S. Wyszyński wiedział, że podjęcie współpracy z rządem musiałoby zakończyć się tak, jak miało to miejsce w Czechosłowacji, czyli upaństwowieniem Kościoła, etatyzacją i tym samym jego likwidacją. Tymczasem Kościół miał być z narodem, a nie z partią i z rządem, bo tylko taki Kościół mógłby być prawdziwie katolicki, spełniający swoją misję.

Prymas mobilizował zatem hierarchów Kościoła do stawiania oporu stalinowskiej władzy, do walki z systemową ateizacją narodu i wydziedziczaniem go z chrześcijańskiej kultury oraz wartości. Miał zresztą własną taktykę walki z bolszewickim reżimem:

[...] taktykę należy ułożyć tak: 1) nie zajmować się wiele zwalczaniem doktryny materialistycznej, gdyż jest ona obca psychice polskiej, jest ciasna sama w sobie, jest antyhumanistyczna; 2) zaostrzyć czujność na odcinku obrony moralności chrześcijańskiej i obyczajowości narodowej; 3) uznać osiągnięcia techniczno-gospodarcze jako dobro rzeczywiste dla rozwoju gospodarki narodowej, nie zwalczać go, a w miarę sposobności popierać33.

Wyszyński zdawał sobie sprawę, że partyjna nomenklatura, z którą musiał się spotykać w sprawach kluczowych dla obrony religii w kraju, nie była z nim szczera. Zło jednak pokonywał miłością, dobrocią, miłosierdziem, gdyż „[...] prawdziwa odbudowa i przebudowa społeczna zacznie się wtedy, gdy sprawiedliwość serce dostanie, i namaszczona będzie miłością" ${ }^{\text {"34 }}$.

Autorka biografii o Wyszyńskim odsłania działania totalitarnej władzy państwowej przeciwko polskiemu Kościołowi katolickiemu i jego Prymasowi, które sprowadzały się m.in. do:

- wbijania klina między hierarchią kościelną a duchowieństwem, rozbijania jej pod pozorem rzekomej demokratyzacji życia w Kościele przez stworzenie ruchu „księży-patriotów”, pozyskanie nielojalnych duchownych do współpracy z Urzędem Bezpieczeństwa (potem przemianowanym na Służbę Bezpieczeństwa) w roli tajnych współpracowników (TW).

Motywy przystępowania do ruchu były różne - od ideologicznych po materialne. Do ruchu wciągano duchownych skłóconych z przełożonymi z powodu czy to przerostu ambicji, czy nadmiaru krytykanctwa, nałogowców złamanych przeżyciami w obozach koncentracyjnych, ale też zwykłych karierowiczów skuszonych obietnicą stanowisk kościelnych albo korzyści materialnych. Jeszcze inni [...] rekrutowali się spośród „oportunistów”, użytecznych idiotów, dziwaków, oderwanych od życia radykałów społecznych. UB [...] pozyskiwało też członków ruchu, stosując „teorię kopa”, czyli szantaż na tle prawdziwych lub wyimaginowanych występków, na przykład seksualnych ${ }^{35}$.

\footnotetext{
33 Wyszyński, Pro Memoria, t. 1: 1948-1952, 103.

34 Za: Czaczkowska, Kardynał, 282.

35 Tamże, 114.
} 
Rząd PRL nie uznawał zwierzchnictwa Stolicy Apostolskiej nad Kościołem w Polsce do lat 70. XX w. Prymasa osaczano agentami, którymi stawali się nie tylko świeccy, w tym pracownicy sekretariatu prymasa, ale - co gorsza - duchowni, w tym także pośród biskupów;

- inwigilowania, podsłuchiwania przez UB, a potem SB najwyższych dostojników Kościoła, a nawet nękania członków rodzin duchownych, ich aresztowania, więzienia. Zanim Wyszyński został prymasem, w latach 1946-1948 donosiło na niego jako biskupa lubelskiego aż 126 tajnych współpracowników UB, a w latach 1948-1963 był osaczony przez aż 28 agentów bezpieki ${ }^{36}$;

- mordowania niepokornych księży i upokarzania więzionych księży diecezjalnych. „Według danych z roku 1956 między rokiem 1945 a styczniem 1953 roku w Polsce zabito 37 księży diecezjalnych, 260 zmarło lub zaginęło, 350 zesłano na Wschód, 700 było w więzieniach, a 900 wygnano z miejsca pobytu"37;

- uderzania w podstawy ekonomiczne i własnościowe Kościoła, żeby zlikwidować jego niezależność. Miał miejsce zatem zabór majątków kościelnych, ale i zakaz budowania nowych kościołów, czy podwyższanie instytucjom kościelnym podatków od dochodów;

- likwidowania w 1960 roku niższych seminariów duchownych oraz w 1961 roku ostatecznego usunięcia religii ze szkół, czemu towarzyszyła dekrucyfikacja, czyli usuwanie symboliki religijnej z placówek oświatowych i instytucji państwowych. Wszystko to sprawiło, że prymas starał się znaleźć w tym jakiś pozytywny element. „Kto wie, czy nie jest to lepsze aniżeli dotychczasowa metoda pomieszania religii z przedmiotami szkolnymi”38;

- cenzurowania wydawnictw katolickich i objęcia pełną kontrolą przez partię władzy aktywności stowarzyszeniowej osób wierzących, ich działalności religijnej, np. w ramach prowadzenia pielgrzymek, letnich obozów i rekolekcji;

- prowadzenia zmasowanych akcji przez Służbę Bezpieczeństwa w postaci preparowania i rozsyłania anonimów, rozsiewania plotek, inspirowania artykułów prasowych celem poniżenia prymasa. To także formułowanie inwektyw przeciwko niemu, kreowanie publicznych dyskusji o wewnętrznych sprawach Kościoła, fabrykowanie listów rzekomo napisanych przez prymasa, pogłębianie konfliktów między biskupami a prymasem oraz zakonami, odmawianie biskupom paszportów na wyjazd do Watykanu czy rekrutowanie spośród profesorów tajnych współpracowników do przygotowywania przez nich dokumentów mających wypaczać wypowiedzi Prymasa, wprowadzać zamieszanie i dezorientację wśród uczestników Soboru Watykańskiego II ${ }^{39}$.

\footnotetext{
36 Tamże, 129.

37 Tamże, 214.

38 Tamże, 142.

39 Tamże, 494-496.
} 
Nie można zapomnieć o tym, że do powstania silnych ruchów opozycji politycznej w PRL znacząco przyczynił się Kościół katolicki, który jako jedyny „[...] publicznie upomniał się o poszanowanie praw i wolności człowieka" ${ }^{40}$. Nie byłoby wielkiego ruchu protestu, „Solidarności” i wolnej Polski bez Kardynała Stefana Wyszyńskiego. Był on bowiem przeciwny nie tylko ideologii komunistycznej, bolszewickiej, socjalistycznej, ale każdej, która w swoich przesłankach gwałciła naturalne prawa człowieka, podporządkowując jego wolę niesprawiedliwym stosunkom społecznym i zawodowym.

Kościół po roku 1956 wiedział dobrze, czego partia dzierżąca władzę nie jest w stanie tolerować. Broniąc narodowej tożsamości, Kościół ma równocześnie jasną świadomość granic, które powinny sobie wyznaczać wszelkie działania ${ }^{41}$.

Prymas był wierny wartościom chrześcijańskim, a więc i prawu naturalnemu osoby do życia, do wolności, do swobody wyznania religijnego, do własności prywatnej i posiadania środków do życia. Ustrój, który naruszał te prawa, był przez niego traktowany jako nośnik niedopuszczalnego zła i przemocy. Wyszyński wierzył, że Kościół przetrwa aż do skończenia świata, i w to, że da sobie radę w każdym okresie, ponieważ dokonuje w najtrudniejszych dla narodu chwilach wielkiego wyzwolenia sumień.

Trzeba pogodzić się z faktem istnienia Kościoła w Polsce. Nie trzeba go nawet uznawać, bo Kościół ma uznanie Jezusa Chrystusa i nie zabiega o względy władz politycznych. Ale trzeba się pogodzić z tym, że Kościół tutaj jest, działa i pracuje, służy i udziela się ubogim; dzięki mocom nadprzyrodzonym i cnotom chrześcijańskim kształci w narodzie postawy społeczne. Taka rzeczywistość jest niewątpliwie korzystna i owocna dla życia publiczno-państwowego ${ }^{42}$.

Nie bez powodu w zakończeniu do niezwykle głębokiego studium na temat formacji chrześcijańskiej dziecka w rodzinie w nauczaniu Kościoła ks. Stanisław Dziekoński stawia jakże trafne pytanie: „[...] jak było w przeszłości? Słuszność tak postawionego problemu wyraża pogląd, że teraźniejszość znajduje swe pełne wytłumaczenie w przeszłości” ${ }^{43}$. Także przyszłość jest teraźniejszością, która staje się przeszłością. Mająca miejsce dechrystianizacja i laicyzacja współczesnej rodziny ma swoje korzenie w poprzednim ustroju. Konieczna jest odwaga w rekonstruowaniu i demistyfikowaniu Zła w każdym wymiarze, nie tylko po to, by je potępiać, ale także by odkryć w sobie dzielność do jego pokonywania. Odzyskaną wolność można bowiem używać dla dobra, dla prawdy i miłości, ale i dla zła, fałszu i wrogości.

Kilkadziesiąt lat zmagań Polaków z totalitaryzmami przyniosło skutek w postaci potrzeby samoobrony przed zniewoleniem całego narodu, ale też

40 Za: Czaczkowska, Kardynał, 343.

${ }^{41}$ Alain Touraine, Solidarność. Analiza ruchu społecznego 1980-1981, tłum. Andrzej Krasiński (Gdańsk: Europejskie Centrum Solidarności, 2010), 123.

${ }_{42}$ Stefan Wyszyński, Prymat człowieka w ładzie społecznym (Londyn: Odnova Ltd., 1976), 136.

${ }^{43}$ Stanisław Dziekoński, Formacja, 545. 
udowodniło, że potrafimy jako naród odzyskiwać i potwierdzać fundamentalne „[...] wartości, jakimi społeczeństwo żyło i jakim pragnęło pozostać wierne. [...] Polacy swoim sprzeciwem wyrażali nie tyle jakiś wybór oparty na motywacjach teoretycznych, ile po prostu to, że nie mogą się nie sprzeciwiać" ${ }^{4}$. Kardynał Stefan Wyszyński był w tym względzie i będzie dla kolejnych pokoleń nauczycielem oporu i dzielności, ubogacającym nas w realizacji programu chrześcijańskiego „Nie daj się zwyciężyć złu, ale zło dobrem zwyciężaj”" Człowiek pozbawiony możliwości wyrażania oporu traci swoją tożsamość.

\section{Pedagogia Prymasa Tysiąclecia}

Wiara, nadzieja i miłość były dla Prymasa najważniejszymi cnotami. „Człowiek odzyskuje wolność wewnętrzną, gdy przebacza i zapomina. A komuż z nas wolność nie jest droga?”46. Jak odnotował w nauczaniu społecznym: „Uważam sobie za łaskę, że mogłem dać świadectwo Prawdzie jako więzień polityczny przez trzyletnie więzienie, i że uchroniłem się przed nienawiścią do moich Rodaków sprawujących władzę w państwie. Świadom wyrządzonych mi krzywd, przebaczam im z serca wszystkie oszczerstwa, którymi mnie zaszczycili" ${ }^{37}$. Wyszyński wyhamowywał gniew, oburzenie na prowadzone przez Służbę Bezpieczeństwa działania podważające jego autorytet. „Człowiek czuje się sponiewieranym, pokrzywdzonym przez kłamliwe zarzuty i naświetlenia. Pozostaje tylko milczenie i świadomość wielkiej niesprawiedliwości, jakiej może doznać człowiek we własnej ojczyźnie, której służy całym życiem, według najlepszego rozumienia swego"48.

Kiedy Wyszyński bronił ostrym językiem spraw polskiego Kościoła w Watykanie, a spotkało się to z krytyką hierarchów uważających, że naraża swój autorytet, odpowiedział:

[...] autorytet po to się ma, by go używać; z chwilą gdy się go nie używa, pomniejsza się go. [...] Nie chodzi przecież o robienie dobrego wrażenia. Byłbym fałszywy [...] gdybym nie podejmował spraw, które są moim obowiązkiem. Dla spełnienia obowiązku, dla prawdy, trzeba się narażać. [...] Nie mogę dopuścić i nie chcę, by Episkopat Polski za ten trudny okres był sądzony i potępiany przez historię. Ciężkie obowiązki trzeba wypełniać nieraz w sposób bolesny ${ }^{49}$.

Prymas Tysiąclecia był zarówno znakomitym nauczycielem, mistrzem skoncentrowanych na wartościach religijnych przemów, kazań, jak i mistrzem milczenia, kiedy wymagała tego od niego troska o dobro wspólne. Okazał się wybitnym

\footnotetext{
44 Jan Paweł II, Pamięć, 52-53.

45 Tamże, 56.

46 Czaczkowska, Kardynat, 280.

47 Tamże, 265.

48 Tamże, 555.

49 Tamże, 563.
} 
wychowawcą Narodu zachęcając do zwalczania wad czy słabości Polaków (nieuczciwość, pijaństwo, nierzetelność, złodziejstwo itp.), do czego inspiracją stawały się inicjowane przez niego wielkie narodowe rekolekcje, jakimi był Czas Wielkiej Nowenny czy obchody Tysiąclecia Chrztu Polski. Jak mówił:

Nie należy oczekiwać zbawienia od innych narodów. Nie wolno osłabiać swojej społecznej postawy i moralnej oczekiwaniem, że inni to za nas zrobią, inni nas wesprą, inni przyjdą z taką czy inną pomocą. Nie! Jest to błąd wychowawczy o założeniu śmiercionośnym. Dlatego nasz naród zawsze musi mieć ambicje wiary we własne siły ${ }^{50}$.

Kardynał S. Wyszyński okazał się także nauczycielem prawdy, protestując przeciwko fałszowaniu historii. Był zarówno dla księży, jak i wiernych, z którymi spotykał się lub dla których prowadził msze święte czy uroczystości religijne, przewodnikiem duchowym i religijnym, mówiąc im prawdę, niczego przed nimi nie ukrywając, a zarazem zobowiązując księży do wytężonej pracy apostolskiej, samokształcenia i pracy nad sobą. Od wszystkich egzekwował karność wewnętrzną i zewnętrzną, gdyż tego samego wymagał od siebie. „Należy podnosić karność zewnętrzną w zachowaniu się zakonników. Należy zabronić wyjazdów do miejsc kuracyjnych, chyba że dla ciężko chorych; należy zabronić używania świeckich ubran'" 51 . Prymas wielokrotnie doświadczył tego, że w państwie nie było warunków do dialogu, ale mimo to zawsze podejmował próby otwierania przestrzeni do jego zaistnienia. Uważał, że każda ze stron powinna być do tego przygotowana nie tylko od strony merytorycznej, ale także, a może przede wszystkim, kulturowej, mentalnej. Jak mówił: „Człowieka trzeba naprzód wychowywać, a później z nim dialogować. [...] ja też jestem za dialogiem, tylko wydaje mi się, że jest on najbardziej skuteczny wtedy, kiedy przynajmniej jedna strona dialogu wie coś na temat, o którym się mówi" ${ }^{2}$.

Oddziaływanie przykładem osobistym nie było dla prymasa jedynie obowiązującą zasadą wychowania, ale zinternalizowaną wartością bycia spójnym w czynach i słowach.

Byłbym złym pasterzem i moglibyście słusznie nie słuchać głosu mego, gdybym od was żądał miłości i przebaczenia wszystkim nieprzyjaciołom, a sam nie stosował się do tego przykazania. Stosuję się do niego w pełni i nikogo na świecie nie uważam za swojego wroga, bo w sercu moim nie znajduję żadnego uczucia wrogości do nikogo ${ }^{53}$.

Jego pedagogia była prospektywna, optymistyczna, pełna chrześcijańskiej miłości bliźniego. Jak pisał w 1949 roku do duchowieństwa Warszawy i Gniezna: „Kościół żyje przez dwadzieścia wieków na ziemi dzięki temu właśnie, że umiał skupiać

\footnotetext{
50 Tamże, 309.

51 Wyszyński, Pro Memoria, t. 1: 1948-1952, 289.

52 Czaczkowska, Kardynat, 356-357.

53 Tamże, 387.
} 
wokół siebie ludzi i budować przyszłość, choćby na ostatnim kamieniu dobra, jaki pozostał jeszcze w duszy, [...] że umiał stanąć przy człowieku, choćby ten stał pod szubienicą" ${ }^{54}$. Wyszyński apelował o to, by zastępować krucjatę nienawiści, wrogości krucjatą miłości, dobroci, budowania kultury serc. Zaproponował wiernym dekalog kultury miłości:

1. Szanuj każdego człowieka, bo Chrystus w Nim żyje. Bądź wrażliwy na drugiego człowieka. Twojego brata.

2. Myśl dobrze o wszystkich - nie myśl źle o nikim. Staraj się nawet w najgorszym znaleźć coś dobrego.

3. Mów zawsze życzliwie o drugich - nie mów źle o bliźnich. Napraw krzywdę wyrządzoną słowem. Nie czyń rozdźwięku między ludźmi.

4. Rozmawiaj z każdym językiem miłości. Nie podnoś głosu. Nie przeklinaj. Nie rób przykrości. Nie wyciskaj łez. Uspokajaj i okazuj dobroć.

5. Przebaczaj wszystko wszystkim. Nie chowaj w sercu urazy. Zawsze pierwszy wyciągaj rękę do zgody.

6. Działaj zawsze na korzyść bliźniego. Czyń dobrze każdemu, jakbyś pragnął, aby Tobie czyniono. Nie myśl o tym, co Tobie jest ktoś winien, ale co Ty jesteś winien innym.

7. Czynnie współpracuj w cierpieniu. Chętnie spiesz z pociechą, radą, pomocą, sercem.

8. Pracuj rzetelnie, bo z owoców Twej pracy korzystają inni, jak ty korzystasz z pracy drugich.

9. Włącz się w społeczną pomoc bliźnim. Otwórz się ku ubogim i chorym. Użyczaj swego. Staraj się dostrzec potrzebujących wokół siebie.

10. Módl się za wszystkich, nawet za nieprzyjaciół ${ }^{55}$.

Pedagogia Prymasa Tysiąclecia wnosi ontologiczną i aksjologiczną odpowiedzialność za jakość naszego życia. Potrzeba szczerej troski o nie, o edukację i wychowanie młodych pokoleń, o wzajemne uczenie się od siebie bez względu na wiek życia, zawsze będzie przenikać wrażliwość na pojawiające się nowe obszary bólu i cierpienia, ale i na introjekcję uniwersalnych wartości, która sprzyjać będzie przełamywaniu konfliktów oraz luki międzygeneracyjnej. Jak trafnie napisał pierwszy rektor Uniwersytetu Łódzkiego, klasyk polskiej filozofii profesor Tadeusz Kotarbiński:

Niech młodzież słucha starszych, to natury kolej,

Tak jeno, nie inaczej, spływa do głów olej.

- Starcze! Tyś sam młodszego instruktora uczeń,

Skoro korzystasz z własnej przeszłości pouczeń ${ }^{56}$

Bądźmy zatem nieposłuszni w myśleniu i działaniu, ponieważ pedagogika oporu wobec zła tworzy język nadziei, kiedy postrzega edukację jako przestrzeń otwarcia

\footnotetext{
54 Tamże, 140.

55 Tamże, 406-407.

56 Tadeusz Kotarbiński, Wesołe smutki (Warszawa: PIW, 1957), 37.
} 
na konflikt, kontestację, ale i autokreację wszystkich jej podmiotów w ich zdolności do czynienia dobra.

St res z c z e n i e: Analiza tekstów źródłowych i wybranych opracowań biografii Kardynała Tysiąclecia Stefana Wyszyńskiego została dokonana z perspektywy zachodzących w Polsce A.D. 2020 procesów sekularyzacji, radykalnego ataku polityków lewicy na Kościół katolicki i jego relacje $\mathrm{z}$ aktualną formacją koalicji Zjednoczonej Prawicy u władzy. Uderza to w fundamenty II Soboru Watykańskiego oraz roli polskiego Kościoła w odzyskaniu przez naród wolności od socjalistycznej dominacji w 1989 roku. Autor przywołuje zatem nie tylko wyjątkowe zasługi Prymasa Polski w okresie totalitaryzmu doby Polski Ludowej w powyższym zakresie, ale i jego przesłanie dla pedagogów, praktyków, rodziców i naukowców.

Słow a klu c z ow e: Kościół katolicki, totalitaryzm, wychowanie, opór, dzielność, etyka, aksjologia, pedagogika

\section{Bibliografia}

Czaczkowska, Ewa K. Kardynał Wyszyński. Biografia. Kraków: Wydawnictwo Znak, 2013.

Dziekoński, Stanisław. Rozwój wychowawczej myśli Kościoła na przestrzeni ostatnich wieków. Warszawa: WN UKSW, 2004.

Dziekoński, Stanisław. Formacja chrześcijańska dziecka $w$ rodzinie w nauczaniu Kościoła od Leona XIII do Jana Pawta II. Warszawa: WN UKSW, 2006.

Grajewski, Andrzej. „Prowadził ich przez mrok”. W: Ewa K. Czaczkowska, Kardynał Wyszyński. Biografia, 5-9. Kraków: Wydawnictwo Znak, 2013.

Hejnicka-Bezwińska, Teresa. „Pedagogika socjalistyczna”. W: Pedagogika, red. Zbigniew Kwieciński, Bogusław Śliwerski, 189-202. Warszawa: WN PWN, 2019.

Hessen, Stefan, Hans, Mikołaj. Pedagogika i szkolnictwo w Rosji Sowieckiej. Rozwój szkolnictwa sowieckiego i zmiany komunistycznej polityki oświatowej od Rewolucji Październikowej do końca planu pięcioletniego (1917-1932), tłum. Adam Zieleńczyk. Lwów-Warszawa: Książnica-Atlas, 1930.

Jan Paweł II. Pamięć i tożsamość. Rozmowy na przełomie tysiącleci. Kraków: Wydawnictwo Znak, 2005. Kamiński, Aleksander. Wielka gra. Warszawa: Niezależne Wydawnictwo Harcerskie, 1981 (reprint 1942).

Kostkiewicz, Janina. Polski nurt krytyki nazizmu przed rokiem 1939. Aspekty ideologiczne i pedagogiczne. Kraków: Wydawnictwo ARCANA, 2020.

Kotarbiński, Tadeusz. Wesołe smutki. Warszawa: PIW, 1957.

Ku pedagogii pogranicza, red. Zbigniew Kwieciński, Lech Witkowski. Toruń: Wydawnictwo UMK, 1990. Mariański, Janusz. Kondycja religijna i moralna młodzieży szkót średnich w latach 1988-1998-2005-2017 (raport z ogólnopolskich badan socjologicznych). Toruń: Wydawnictwo Adam Marszałek, 2018.

Markowski, Michał, P. Wojny nowoczesnych plemion. Spór o rzeczywistość w epoce populizmu. Kraków: Wydawnictwo Karakter, 2019.

Rastawicka, Anna. Ten zwycięża, kto miłuje, Mt 5,14. Warszawa: Muzeum Jana Pawła II i Prymasa Wyszyńskiego, 2020.

Rynio, Alina. Wychowanie młodzieży w nauczaniu Kardynała Stefana Wyszyńskiego. Lublin: Redakcja Wydawnictw KUL, 1995.

Stalinizm, red. Jacek Kurczewski. Warszawa: Uniwersytet Warszawski. Instytut Profilaktyki Społecznej i Resocjalizacji, 1989.

Śliwerski, Bogusław. Współczesne teorie i nurty wychowania. Kraków: Impuls, 1998. 
Śliwerski, Bogusław. [Kontr] rewolucja oświatowa. Studium z polityki prawicowych reform edukacyjnych. Łódź: WUŁ, 2020.

Touraine, Alain. Solidarność. Analiza ruchu społecznego 1980-1981, tłum. Andrzej Krasiński. Gdańsk: Europejskie Centrum Solidarności, 2010.

Wyszyński, Stefan. Duch pracy ludzkiej. Konferencje o pracy. Włocławek: Księgarnia Powszechna, 1946. Wyszyński, Stefan. Prymat człowieka w ładzie społecznym. Londyn: Odnova Ltd., 1976.

Wyszyński, Stefan. Pro Memoria, t. 1: 1948-1952. Warszawa: Archidiecezja Warszawska i Archidiecezja Gnieźnieńska, IPN - Komisja Ścigania Zbrodni przeciwko Narodowi Polskiemu, UKSW, 2017.

Wyszyński, Stefan. Pro Memoria, t. 2: 1953. Warszawa: Archidiecezja Warszawska i Archidiecezja Gnieźnieńska, IPN - Komisja Ścigania Zbrodni przeciwko Narodowi Polskiemu, UKSW, 2017.

Wyszyński, Stefan. Pro Memoria, t. 3: 1953-1956. Warszawa: Archidiecezja Warszawska i Archidiecezja Gnieźnieńska, IPN - Komisja Ścigania Zbrodni przeciwko Narodowi Polskiemu, UKSW, 2018. 